\title{
Intracranial Lipoma
}

National Cancer Institute

\section{Source}

National Cancer Institute. Intracranial Lipoma. NCI Thesaurus. Code C5444.

A rare benign adipose tissue neoplasm located in the intracranial region. It is a congenital hamartomatous malformation derived from the embryologic meninx primitiva. 